\title{
The paradox of minority attorney satisfaction
}

Milan Markovic

Texas A\&M University School of Law, mmarkovic@law.tamu.edu

Gabrielle Plickert

California State Polytechnic University - Pomona

Follow this and additional works at: https://scholarship.law.tamu.edu/facscholar

Part of the Law and Economics Commons, Law and Society Commons, and the Legal Profession Commons

\section{Recommended Citation}

Milan Markovic \& Gabrielle Plickert, The paradox of minority attorney satisfaction, 60 Int'l Rev. L. \& Econ. 1 (2019).

Available at: https://scholarship.law.tamu.edu/facscholar/1443

This Article is brought to you for free and open access by Texas A\&M Law Scholarship. It has been accepted for inclusion in Faculty Scholarship by an authorized administrator of Texas A\&M Law Scholarship. For more information, please contact aretteen@law.tamu.edu. 


\title{
The paradox of minority attorney satisfaction ${ }^{\text {is }}$
}

\author{
Milan Markovic ${ }^{\mathrm{a}, *}$, Gabriele Plickert $^{\mathrm{b}}$ \\ a Texas AEM University School of Law, 1515 Commerce Street, Fort Worth, Texas 76102, USA \\ b Department of Sociology, California State Polytechnic University Pomona, 3801 West Temple Avenue, Pomona, CA 91768, USA
}

\section{A R T I C L E I N F O}

\section{Article history:}

Received 17 June 2019

Received in revised form

13 September 2019

Accepted 14 September 2019

Available online 27 September 2019

\section{Keywords:}

Satisfaction

Minority attorneys

Ordered logit regression

\begin{abstract}
A B S T R A C T
A substantial literature documents the challenges faced by minority attorneys in the legal profession, ranging from underrepresentation in prestigious practice settings and lower incomes to discrimination from fellow lawyers, clients, and judges. In light of the foregoing, one would expect minority attorneys to regret their decisions to attend law school and become lawyers. Yet, empirical research indicates that minority attorneys are predominately satisfied with their decision to become attorneys and that their satisfaction is on par with that of white attorneys. How to account for this seeming paradox?

Drawing on data from a large cross-section of Texas lawyers, this is the first study to address and assess empirically the paradox of minority attorney satisfaction. We provide evidence that the drivers of white and minority attorneys' satisfaction differ and may be rooted in different value systems. In particular, minority attorneys' satisfaction is unaffected by their academic performance in law school or earnings from legal practice. Moreover, they are especially satisfied in nominally low status solo practitioner positions. This article concludes by advancing possible explanations for these differences.
\end{abstract}

(c) 2019 Elsevier Inc. All rights reserved.

\section{Introduction}

Racial minorities are largely absent from foundational studies of the American legal profession (Heinz and Laumann, 1982: 6; Smigel, 1964: 45). Only as institutionalized discrimination receded in recent decades have minorities joined the "lawyer governing class" in greater numbers and become a major subject of inquiry (Pearce, 2001: 381). ${ }^{1}$

A substantial body of research now documents the challenges faced by minority attorneys. Racial minorities are underrepresented in law schools and are at increased risk of failing the bar exam (Clydesdale, 2014:752-53; Wald, 2011:1108). They also constitute a small percentage of practicing lawyers. According to the Bureau of Labor Statistics, only $4.4 \%$ of attorneys are Black and $5.6 \%$ are Hispanic. ${ }^{2}$ Integration remains elusive, with minorities less

\footnotetext{
This research benefited from the grant support of the AccessLex Institute, Directed Grants Program, accessible under: https://www.accesslex.org/research/ awarded-grants?f[0]=nid:235\#.

* Corresponding author.

E-mail addresses: mmarkovic@law.tamu.edu (M. Markovic), gplickert@cpp.edu (G. Plickert).

1 We use the terms "minority attorneys" and "non-white attorneys" to mean Black and Hispanic attorneys unless otherwise specified. As noted in the limitations section, there may be important differences between groups of minority attorneys that are beyond the purview of this study.

2 See BLS, Labor Force Statistics from the Current Population Survey (2016), at https://www.bls.gov/cps/cpsaat11.htm.
}

likely to work in corporate law firms and more likely to work in government and in smaller firms (Gorman and Kay, 2010: 222; Johnson, 1997:1037-38; Sommerlad, 2011: 2487). Minority attorneys who are employed by corporate firms struggle to locate mentors, receive lower quality work assignments, and disproportionately depart without making partner (Payne-Pikus et al., 2010: 559-60; Sander, 2006: 1759; Woodson, 2016: 111).

Whatever their settings, minorities face subtle and not-sosubtle discrimination such as being mistaken for, inter alia, court reporters, secretaries, and even criminal defendants (Collins et al., 2017: 1642; Cruz and Molina, 2009: 1010-11). They also earn less than white attorneys; some studies suggest tens of thousands of dollars a year less (Dau-Schmidt and Mukhopadhaya, 1999:358-59; McIntyre and Simkovic, 2017: 2, 9; Stake et al., 2007; 962-63).

In light of the forgoing, one would expect minority attorneys to be dissatisfied with their decisions to become attorneys or, at minimum, to be less satisfied than their white counterparts. Yet, several empirical studies, mostly focusing on Black attorneys, have observed that minority attorneys' satisfaction is equivalent to that of white attorneys (Dau-Schmidt and Mukhopadhaya, 1999:36263; Lempert et al., 2000: 445-47). The nationally representative After the JD Study ("AJD") suggests that Black and Hispanic attorneys are among the most satisfied attorneys: In AJD's second wave, $80 \%$ of these attorneys indicated that they were at least moderately satisfied with their decisions to become attorneys (Dinovitzer et al., 2009a,b). Moreover, racial minorities' satisfaction in the legal profession cannot be reduced to their tendency to work in more sat- 
isfying legal practice settings (Lempert et al., 2000: 446-47). How to reconcile the challenges faced by minority attorneys in a whitedominated legal profession with their high levels of satisfaction?

This is the first study to address and assess empirically this paradox of minority satisfaction. Using a sample that consists of substantial numbers of white, Hispanic, and Black attorneys, we also seek to ascertain whether the drivers of satisfaction differ based on race. In particular, we theorize that minority attorneys' satisfaction is not predicated on the attainment of prestige markers such as high incomes and partnership in prestigious law firms that have been the principal focus of legal profession researchers. Rather, racial minorities are able to derive high levels of satisfaction from membership in the legal profession by forming professional identities that are not fully "bleached out" (Levinson, 1993:1578; Wilkins, 1998: 1504).

We begin by reviewing the research on satisfaction in the legal profession, focusing particularly on explanations of racial differences in satisfaction. We then describe the survey data and the incorporated measures that provide evidence of a paradox of minority attorney satisfaction among minority attorneys in Texas. We then test our theory that the paradox can be attributed to the different drivers of white and minority attorneys' satisfaction. We conclude by suggesting that white and minority attorneys may manifest different value systems and identify potential sources of these differences.

\section{Background}

Social scientists have long studied occupational satisfaction and sought to compare the satisfaction of different groups. For example, a robust literature has found that male and female workers have similar levels of career satisfaction despite discrepancies in pay and in work conditions (Clark, 1997: 341; Hodson, 1989: 385). Scholars have sought to attribute this "paradox of the contented female worker" to women's purported comparison of their careers to those of other women, lower career expectations, and emphasis on intrinsic as opposed to extrinsic rewards from work (Mueller and Williams, 1996: 346-48; Phelan, 1994: 95-107). Researchers have also focused on the possible synergy between women's professional roles and roles as wives and mothers (Rogers and May, 2003: 493; Roxburgh, 1999: 784-85).

Empirical research has also examined racial differences in job satisfaction, primarily between white and black workers (WeiCheng and Kopischke, 2001: 142). According to most studies, racial minorities report lower job satisfaction and place more emphasis on extrinsic job rewards such as job security and income than their white colleagues do (Koh et al., 2016: 137; Kashefi, 2011: 657; Weaver, 1998:1087). ${ }^{3}$ However, minorities who are able to overcome economic and social disadvantages and obtain high-status positions report the same satisfaction as their white counterparts (Koh et al., 2016: 136; Kashefi, 2011: 644). Educational attainment provides racial minorities with the cognitive and emotional skills to cope with discriminatory experiences while "instilling meaning, purpose, pride, and a commitment to self-realization" (Ryff et al., 2003: 288).

Lawyers are highly educated professionals who work in a field dominated by white men (Sommerlad, 2007: 200-202). Nevertheless, outsider groups report high career satisfaction in the legal profession. For example, female attorneys are as satisfied with the context and content of their work as their male counterparts notwithstanding unequal pay and advancement opportunities (Hull, 1995: 695; Kay and Gorman, 2008: 316). Hull has described

\footnotetext{
3 For opposing studies, see Brush et al., 1987; Bartel, 1981: 298.
}

this phenomenon the "paradox of the contented female lawyer" (Hull, 1999: 688).

Racial differences in attorneys' career satisfaction have received far less scrutiny. Some longitudinal studies report that there are no significant racial differences in satisfaction across practice settings (Dinovitzer et al., 2009a,b; Lempert et al., 2000: 445-47). But much of the existing scholarship concentrates on specific contexts such as large corporate law firms that are not representative of minorities in the legal profession generally (Payne-Pikus et al., 2010: 553). Even in such settings, researchers have discerned only minor differences. For example, Payne-Pikus et al. found statistically significant differences in satisfaction between white and African-American associates but not between white and Hispanic associates (2010:569).

Heretofore there has been no systematic appraisal of racial minorities' satisfaction in the legal profession. Researchers have by and large assumed that minority attorneys have internalized legal profession hierarchies that privilege lucrative corporate work over the provision of legal services to ordinary individuals (Foley et al., 2002: 490; Johnson, 1999: 1014-20; Payne-Pikus et al., 2010: 559-60). However, as critical race theorists have emphasized, to understand the experiences of racial minorities, researchers must "look to the bottom" (Matsuda, 1987:325) and eschew "onesize-fits-all” frameworks (Bell and Hartmann, 2007: 908; Hylton, 2012:26). Just as female attorneys' satisfaction is not dependent on equivalent earnings to men (Mueller and Wallace, 1996: 346) or participation in elite modes of practice (Menkel-Meadow, 1989: 307), there is no a-priori reason to believe that minority attorneys assess their careers with reference to their ability to ascend to the top of the legal profession pyramid via service to corporate clients (Fortney, 1994: 337).

This article augments existing research on minority attorneys' professional satisfaction by recognizing that legal profession hierarchies are not "normal and natural" and may not be determinative of minority attorneys' satisfaction (Ladson-Billings, 2010:11). In particular, the rise of the corporate law firm as "the pinnacle of professional aspiration and power" (Auerbach, 1976:22) occurred during a period when racial minorities were excluded from the legal profession; lawyers' assessments of prestige in the modern day echo those of lawyers who practiced during this period of racial exclusion (Heinz et al., 2005: 88). The focus on high-earning lawyers in corporate law firms also obscures that rewarding careers exist in other settings and that public interest and government attorneys are often among the most satisfied attorneys (Markovic and Plickert, 2018: 153; Krieger and Sheldon, 2015: 591).

Rather than accepting "white structures" as the normative baseline (Carbado, 2011: 1612), we theorize that different factors drive the satisfaction of white and non-white attorneys and that these differences give rise to the paradox of minority attorney satisfaction. Minority attorneys may be aware of prevailing hierarchies that pre-dated their entry into the profession while being motivated by altogether different factors. Indeed, as suggested by some previous research, in comparison to their white counterparts, racial minorities are more likely to view professional careers as a calling (Ryff et al., 2003: 286). They are also more interested in serving, and seeking justice for, their historically disadvantaged communities (Pan, 2017: 27-32; Pratt, 2012: 1792-93; Sommerlad, 2007: 204). Once in practice, they more often "give back" to their communities by engaging in non-remunerative service (Lempert et al., 2000: 455-58). Following Wilkins, we maintain that minority attorneys may find satisfaction in the legal profession not by subsuming their racial identities but by implicitly or explicitly rejecting "bleached out professionalism" (Wilkins, 1998: 143). 


\section{Data and methods}

\subsection{The survey}

In collaboration with the State Bar of Texas ("State Bar") Department of Research and Analysis the investigators surveyed active State Bar members concerning their satisfaction with their decisions to attend law school, a precursor to membership in the legal profession. ${ }^{4}$ The survey included questions regarding occupational settings (e.g., private practice, government, public interest, etc.), gender, race/ethnicity, age, years of practice experience, region, law school debt (both, debt incurred from law school as well as remaining debt), and education (college major, college and law school rank). Private practitioners received additional questions about the size of their firms (all locations) and roles within their firms.

The surveys were disseminated in March 2016 and closed in mid-April 2016. Nearly 13\% of surveyed State Bar members provided responses. This response rate is consistent with other recent large scale-surveys of lawyers. ${ }^{5}$ For example, Krieger and Sheldon report a response rate of $12.7 \%$, with individual state response rates varying from $8.8 \%$ to $15.8 \%$ (2015:571).

The sampling frame includes the 254 counties of Texas and consists of more than 11,000 lawyers who are active members of the State Bar. The racial composition of the dataset is $80 \%$ white, $11 \%$ Hispanic and $4 \%$ Black. ${ }^{6}$ This racial distribution is similar to that of the State Bar as a whole. ${ }^{7}$ Respondents are also similar to State Bar members across other professional and demographic characteristics, except for the slight overrepresentation of government attorneys and younger, less experienced attorneys. ${ }^{8}$ To test for a paradox of minority attorney satisfaction across practice settings, we focus only on full-time attorneys. The final study sample consisted of 7279 white attorneys and 1449 minority attorneys.

\subsection{Measures}

\subsubsection{Dependent variable}

The following measures are used to analyze whether i) a paradox of minority attorney satisfaction exists and ii) whether different factors drive white and minority attorneys' satisfaction and may help to account for any such paradox.

Attorney Satisfaction. The outcome variable refers to respondents' answers to the following question: "How satisfied are you with your decision to attend law school?" Respondents rated their satisfaction on a five-point Likert-type scale with the follow-

\footnotetext{
4 One cannot become a lawyer in Texas without completing law school. See 19 Tx. Gov. Code $\S 81.051$

5 To ensure that our satisfaction results were not affected by nonresponse bias, we used late responders as surrogates for nonrespondents and compared this group to early responders (Lindner et al., 2001: 251; Armstrong and Overton, 1977: 397). Using this method, we found no significant differences in either career satisfaction or satisfaction with the decision to attend law school between early and late responders, suggesting that the results are unaffected by nonresponse bias.

${ }^{6}$ Approximately $3 \%$ of survey respondents classified as Asian. These attorneys, as well as the $1 \%$ of attorneys who classified themselves in the ambiguous "other" category were excluded from the final study sample. Previous research has shown that Asian attorneys largely resemble white attorneys in terms of their occupational practice settings and incomes and therefore high satisfaction among this group would not evince a paradox of satisfaction (Dinovitzer et al., 2014a,b: 75-77)

7 See State Bar of Texas Membership: Attorney Statistical Profile (2016-2017) at, https://www.texasbar.com/AM/Template.cfm?Section=Demographic_and_ Economic_Trends\&Template=/CM/ContentDisplay.cfm\&ContentID=35991.

${ }^{8}$ Among the survey respondents, $45 \%$ are forty and younger and $44 \%$ of respondents have been practicing for ten years or less. Among the State Bar membership as a whole, $36 \%$ of attorneys are forty and younger, and $30 \%$ have been practicing for ten years or less. See State Bar of Texas, State Bar of Texas Membership: Attorney Statistical Profile (2015-2016), at https://www.texasbar.com/AM/Template. $\mathrm{cfm}$ ?Section=Demographic_and_Economic_Trends\&Template=/CM/ContentDisplay. cfm\&ContentID=32670.
}

ing response set: $1=$ very dissatisfied, $2=$ dissatisfied, $3=$ neither, $4=$ satisfied, and $5=$ very satisfied. We follow Kricheli-Katz and colleagues (2018: 452) by focusing on the decision to attend law school - as opposed to the decision to become a lawyer because legal training can be deployed outside of legal practice, and some individuals who are licensed to practice law may have never intended to become lawyers. Our findings are consistent with this claim since $3 \%$ of the white attorneys and $4 \%$ of the minority attorneys in our Texas dataset work full-time in non-law related fields, and higher percentages work in in-house positions that frequently involve both lawyer and non-lawyer tasks (see Table 1, infra). Career path choice also provides a broader indication of respondents' interests and preferences and is less likely to be conditioned by one's immediate environment than job setting satisfaction (Dinovitzer and Garth, 2007:21).

Research relating to satisfaction outcomes typically estimates ordinal scales, ranging from three categories to five or ten-point Likert scales (Fullerton, 2009). For our final analyses, we leave the outcome variable in its original ordinal five-point Likerttype scale so as not to lose any of the variation that is typical when ordinal variables are collapsed into fewer categories (Allison, 2012).

\subsubsection{Independent variables}

3.2.2.1. Income. This variable refers to respondents' gross income in 2015, inclusive of bonus. Given the highly skewed nature of the distribution, we logged income in the analyses.

3.2.2.2. Law school class rank. We assessed respondents' class rank with the question: "Which of the following best describes your class rank upon graduation from law school?" Possible response choices were: (1) $10^{\text {th }}$ percentile, (2) $25^{\text {th }}$ percentile, (3) $50^{\text {th }}$ percentile, (4) $75^{\text {th }}$ percentile, and (5) don't know. In our analysis, we exclude the "don't know" responses. We estimate the effects of the $10^{\text {th }}, 25^{\text {th }}$, $50^{\text {th }}$, and $75^{\text {th }}$ percentile. The $50^{\text {th }}$ percentile is the omitted class rank category.

3.2.2.3. Years of practice experience. We asked respondents to report their years of law practice experience (up to and including calendar year 2015). Experience is measured in years ranging from 2 or fewer years of experience to more than 25 years of experience. Higher values refer to more years of experience. Some research has indicated that older attorneys tend to be more satisfied than younger ones (Organ, 2011: 229).

3.2.2.4. Law school debt. Respondents were asked: "At this point in your career, how much law school debt do you have remaining? The remaining debt is measured in dollar amounts. Respondents with zero debt remaining are the comparison group. There has been significant speculation concerning law school debt's effects on lawyers' satisfaction (Dinovitzer et al., 2014a,b: 218).

3.2.2.5. Firm size. To assess firm size, we asked respondents: "For 2015, how many attorneys, including yourself, worked in your firm?" Attorneys were instructed to consider all of their firms' office locations. Firm size is treated as a continuous measure, ranging from 1 to 1880 . Firm size's effects on income and satisfaction have been noted in other studies (Dau-Schmidt and Mukohpadhaya, 1999: 362; Krieger and Sheldon, 2015: 596).

3.2.2.6. Occupation. Survey participants were asked: “For 2015 , what was your primary occupation?" We created five dummy codes for occupation: (1) for-profit corporate/in-house counsel, (2) government, (3) non-profit/ public interest, and (4) non-law 
Table 1

Summary Statistics for all Study Variables.

\begin{tabular}{|c|c|c|c|c|c|c|}
\hline \multirow[b]{2}{*}{ Variables } & \multicolumn{2}{|c|}{ Minority N = 1449} & \multicolumn{2}{|c|}{ White $\mathrm{N}=7279$} & \multirow[b]{2}{*}{ Min } & \multirow[b]{2}{*}{ Max } \\
\hline & Mean & SD & Mean & SD & & \\
\hline Satisfaction & 4.02 & 1.12 & 4.02 & 1.11 & 1 & 5 \\
\hline Years of Experience & $3.52^{\mathrm{a}}$ & 1.99 & 4.29 & 2.16 & 1 & 7 \\
\hline \multicolumn{7}{|l|}{ Law School Performance } \\
\hline $10^{\text {th }}$ percentile & $.14^{\mathrm{a}}$ & - & .23 & - & 0 & 1 \\
\hline $25^{\text {th }}$ percentile & .30 & - & .34 & - & 0 & 1 \\
\hline $50^{\text {th }}$ percentile & $.41^{\mathrm{a}}$ & - & .34 & - & 0 & 1 \\
\hline $75^{\text {th }}$ percentile & $.14^{\mathrm{a}}$ & - & .08 & - & 0 & 1 \\
\hline Personal Income (Logged) & $11.45^{\mathrm{a}}$ & .70 & 11.73 & .81 & 1.79 & 15.42 \\
\hline Firm size & 22.00 & 37.82 & 23.40 & 39.72 & 1 & 1880 \\
\hline Debt remaining & $.66^{\mathrm{a}}$ & - & .46 & - & 0 & 1 \\
\hline Metropolitan Area & .76 & - & .81 & - & 0 & 1 \\
\hline \multicolumn{7}{|l|}{ Occupation } \\
\hline Private Practice & $.57^{\mathrm{a}}$ & - & .65 & - & 0 & 1 \\
\hline In-house counsel & $.09^{\mathrm{a}}$ & - & .12 & - & 0 & 1 \\
\hline Non-profit/public interest & $.06^{\mathrm{a}}$ & - & .03 & - & 0 & 1 \\
\hline Government & $.23^{\mathrm{a}}$ & - & .16 & - & 0 & 1 \\
\hline Non-law & .04 & - & .03 & - & 0 & 1 \\
\hline \multicolumn{7}{|l|}{ Role } \\
\hline Solo & $.35^{\mathrm{a}}$ & - & .29 & - & 0 & 1 \\
\hline Associate & $.36^{\mathrm{a}}$ & - & .30 & - & 0 & 1 \\
\hline Equity Partner & $.17^{\mathrm{a}}$ & - & .25 & - & 0 & 1 \\
\hline Non-equity Partner & $.04^{\mathrm{a}}$ & - & .07 & - & 0 & 1 \\
\hline Other & .06 & - & .07 & - & 0 & 1 \\
\hline Female & $.56^{\mathrm{a}}$ & - & .37 & - & 0 & 1 \\
\hline
\end{tabular}

Note: ${ }^{\text {a }}$ Mean comparisons are significantly different from white attorneys at $p<.05$.

related and (5) private law practice, which serves as the reference group.

3.2.2.7. Role. Private practitioners, but not other attorneys, were asked to provide their roles within their law firms. Role is composed of six dummy codes: (1) associate, (2) equity partner, (3) non-equity partner, (4) other (e.g., contract attorney), and (5) solo practitioner. ${ }^{9}$ To estimate the effects of attorney role on satisfaction, we use associates as the reference group.

Region is a binary variable, coded 1 for metropolitan area and 0 for non-metropolitan area. We rely upon the Federal Office of Management and Budget's classifications for metropolitan and non-metropolitan areas.

3.2.2.8. Key control variables. Gender is coded 1 for women and 0 for men. For respondents' race and ethnicity, we contrast "Minority," coded 1 with "White," coded 0.

Table 1 reports the descriptive statistics used in the study by race.

\subsection{Analytical approach}

To examine the paradox of minority satisfaction, we estimated a series of ordered logit regression models, a suitable technique for the ordinal nature of our outcome variable. As a means of analyzing ordinal dependent variables, the assumptions of the proportional odds model must be met (McCullagh, 1980). Understanding the nature of the categorical outcome (ordered vs. unordered), the proportional odds model assumes that the cut points between categories are unknown (Long and Cheng, 2004).

We first tested whether the proportional odds assumptions were met for our logit regression models with the ordered outcome. The proportional odds test leads us assume that the categories of

${ }^{9}$ A relatively small number of attorneys described themselves as "counsel." Because of the ambiguity of this role, they were excluded from the analyses of private practitioners' satisfaction. the outcome are ordered in the sequence $j=1, \ldots J$. Thus the cumulative probabilities are defined as

$F_{i j}=\sum_{m=j}^{J} p_{m}$

Where $F_{i j}$ is the probability that individual $i$ is in the $j^{\text {th }}$ category or higher. Each $F_{i j}$ corresponds to a different dichotomization of the five point outcome variable. The then specified the model as following with a set of $J-1$ equations,

$\log \left(\frac{F_{i j}}{1-F_{i j}}\right)=\alpha_{j}+\beta \mathbf{X}_{\mathrm{i}} \mathrm{j}=1, \ldots, \mathrm{J}-1$

where $\beta \mathrm{x}_{\mathrm{i}}=\beta_{1} \mathrm{x}_{i 1}+\ldots+\beta_{k} \mathrm{x}_{i \mathrm{k}}$.

The ordered logit models include only one set of coefficients but different intercepts (cut points) for each of the equation (see also Allison, 2012). In our models, positive estimates correspond to positive relationships for satisfaction while negative coefficients indicate increases in the explanatory value, leading to less satisfaction.

For the ordered logit regression analyses, we first regressed attorney satisfaction by occupation (Table 2), including the explanatory variables of gender, race, law school performance, income, debt, and region. We then conducted a separate analysis for the subsample of private practitioners while adding firm size and role to our analysis (Table 3). The second set of ordered logit regression models separately regressed minority and white attorneys' satisfaction (Table 4) and then that of minority and white private practitioners (Table 5), once again including all independent measures and control variables.

\section{Findings}

\subsection{Evidence for the paradox}

We first examine the data for evidence indicative of a paradox of minority attorney satisfaction. If the notion of a paradox is supported, we would expect minority attorneys to work in nominally 
Table 2

Attorneys' Satisfaction by Occupation (ordered logit).

\begin{tabular}{llll}
\hline & Estimate & Std. Err & Odds \\
\hline Female $^{\mathrm{a}}$ & $.176^{* * *}$ & .052 & 1.192 \\
Minority & $.409^{* * *}$ & .070 & 1.505 \\
Years of Experience & $.103^{* * *}$ & .015 & 1.108 \\
Class rank $^{\mathrm{b}}$ & & & \\
$\quad 10^{\text {th }}$ percentile $^{\text {th }}$ & $.469^{* * *}$ & .069 & 1.598 \\
$5^{\text {th }}$ percentile & $.301^{* * *}$ & .059 & 1.361 \\
$7^{\text {th }}$ percentile & -.097 & .086 & .908 \\
Income (logged) & $.349^{* * *}$ & .035 & 1.417 \\
Metropolitan Area & $-.169^{*}$ & .064 & .845 \\
Debt remaining & $-.162^{* * *}$ & .016 & .851 \\
Occupation & & & \\
In-house counsel & $-.180^{*}$ & .078 & .836 \\
Non-profit/public interest & .125 & .138 & 1.133 \\
Government & -.071 & .069 & .932 \\
$\quad$ Non-law & $-.657^{* * *}$ & .141 & .519 \\
Intercept 5 & -4.471 & .450 & \\
Intercept 4 & -3.124 & .448 & \\
Intercept 3 & -1.859 & .448 & \\
Intercept 2 & -.720 & .450 & \\
LR $\chi^{2}$ & 814.21 & & \\
Prob > $\chi^{2}$ & .000 & & \\
Pseudo R-Square & .151 & & \\
$\mathrm{~N}$ & & &
\end{tabular}

Note: ${ }^{*} p<.05 ;{ }^{* *} p<.01 ;{ }^{* * *} p<.001$ (two-tailed test).

Includes information of the final sample of all full-time attorneys.

a Reference is male.

b Class rank, reference is $50^{\text {th }}$ percentile class rank.

c Metropolitan Area $=1$ and non-metropolitan $=0$.

d Occupation, reference group is private practice.

Table 3

Private Practitioners' Satisfaction by Role (ordered logit).

\begin{tabular}{|c|c|c|c|}
\hline & Estimate & Std. Err & Odds \\
\hline Female $^{\mathrm{a}}$ & $.243^{* * *}$ & .067 & 1.275 \\
\hline Minority & $.456^{* * *}$ & .092 & 1.578 \\
\hline Years of Experience & $.112^{* * *}$ & .021 & 1.118 \\
\hline \multicolumn{4}{|l|}{ Class rank $\mathrm{b}^{\mathrm{b}}$} \\
\hline $10^{\text {th }}$ percentile & $.414^{* * *}$ & .086 & 1.513 \\
\hline $25^{\text {th }}$ percentile & $.175^{*}$ & .073 & 1.191 \\
\hline $75^{\text {th }}$ percentile & -.061 & .114 & .941 \\
\hline Income (logged) & $.374^{* * *}$ & .048 & 1.454 \\
\hline Metropolitan Area ${ }^{c}$ & -.151 & .079 & .859 \\
\hline Debt remaining & $-.139^{* * *}$ & .020 & .870 \\
\hline \multicolumn{4}{|c|}{ Private Practice Characteristics } \\
\hline Firm Size & .033 & .008 & 1.033 \\
\hline \multicolumn{4}{|l|}{ Role $^{\mathrm{d}}$} \\
\hline Solo & $.296^{* * *}$ & .087 & 1.344 \\
\hline Equity Partner & .109 & .108 & 1.115 \\
\hline Nonequity & -.031 & .135 & .969 \\
\hline Other & -.232 & .134 & .793 \\
\hline Intercept 5 & -5.082 & .564 & \\
\hline Intercept 4 & -3.721 & .562 & \\
\hline Intercept 3 & -2.442 & .561 & \\
\hline Intercept 2 & -1.374 & .553 & \\
\hline $\mathrm{LR} \chi^{2}$ & 539.080 & & \\
\hline Prob $>\chi^{2}$ & .000 & & \\
\hline Pseudo R-Square & .153 & & \\
\hline $\mathrm{N}$ & 6052 & & \\
\hline
\end{tabular}

Note: ${ }^{*} p<.05 ;{ }^{* *} p<.01 ;{ }^{* * *} p<.001$.

* Includes information only of all full-time working attorneys in private practice.

a Reference is male.

b Class rank, reference is $50^{\text {th }}$ percentile class rank.

c Metropolitan $=1$ and non-metropolitan $=0$.

d Role $=$ reference group is associate attorney.

less prestigious settings and roles and to have lower incomes than white attorneys but to express high satisfaction with their decisions to attend law school.

\subsubsection{Minority attorneys' underrepresentation in more prestigious settings}

Lawyers generally regard law firm practice, particularly in large corporate law firms, as far more prestigious than solo practice, government, and public interest employment (Heinz et al., 2005: 95-96). In light of this longstanding fragmentation of the profession into "two hemispheres" (Heinz and Laumann, 1982: 23), commentators have lamented that minority attorneys are underrepresented in corporate law firms and overrepresented in less prestigious strata of the legal profession. When racial minorities do work in corporate firms, they are overwhelmingly in associate positions and not partners (Sander, 2006: 1781; Wilkins and Mitu Gulati, 1996: 541-42). These lower status positions allegedly stigmatize minority attorneys (Johnson, 1997:1037-38) and undermine their ability to effectuate societal change (Carle, 2001: 728-29).

In general, our descriptive results support that minority attorneys work in practice settings that are commonly characterized as less prestigious. As set out in Table 1, minority attorneys more commonly work in government and in public interest than do white attorneys. Fewer minorities also work in private practice in contrast to their white counterpart. Our data do not allow us to determine whether these differences are the product of individual preferences or labor market dynamics (including possible employer bias).

Table 1 also indicates that, among private practitioners, racial differences in job setting are not as evident, and white and non-white attorneys work in similarly sized firm. However, the attorneys differ in their roles within firms. Minority attorneys more often work as solo practitioners than white attorneys. In addition, they are more commonly employed as associates and less commonly as partners: $25 \%$ of white attorneys in our study sample are equity partners compared to $17 \%$ of minority attorneys. Our descriptive findings are consistent with previous research that suggests that minority attorneys occupy nominally less prestigious positions and that differences in occupational settings and attorneys' roles within firms are more salient than differences in firm size (Gorman and Kay, 2010: 222).

\subsection{Minority attorneys' incomes}

Minority attorneys report lower incomes than their white counterparts, although studies differ on the magnitude of these differences (Dau-Schmidt et al., 2006: 1464; Stake et al., 2007; 96263). Most of these studies have examined relatively small cohorts of minority attorneys such as graduates of specific law schools (Lempert et al., 2000; Stake et al., 2007) or minority attorneys who practice in large cities like Chicago (Heinz et al., 2005: 273). Our study sample includes substantial numbers of white, Black and Hispanic attorneys who practice in all parts of Texas and who vary substantially in their backgrounds and stages of their careers.

We find significant differences in logged income between white and non-white attorneys in Table $1 .{ }^{10}$ Among all full-time lawyers who make up our study sample, white attorneys earn a median income of $\$ 120,000$ compared to a median income of $\$ 92,500$ for minority attorneys. Some of this difference is undoubtedly attributable to minority attorneys' overrepresentation in relatively low-paying government and/or public interest positions. Nevertheless, racial disparities persist when we account for only for white and minority private practitioners in the study sample. The median

\footnotetext{
10 See Table 1 for differences in logged income. The difference is significant at the $\mathrm{p}<.01$ for unlogged income. Consistent with our finding, Simkovic and McIntyre recently estimated that white male attorneys earn an average of $\$ 180,000$ a year compared to $\$ 153,000$ for Hispanic male attorneys and $\$ 126,000$ for Black attorneys (2017: 22).
} 
Table 4

Minority and White Attorneys' Satisfaction by Occupation (ordered logit).

\begin{tabular}{|c|c|c|c|c|c|c|}
\hline & \multicolumn{3}{|l|}{ Minorities } & \multicolumn{3}{|l|}{ White } \\
\hline & Estimate & Std. Err & Odds & Estimate & Std. Err & Odds \\
\hline Female $^{\mathrm{a}}$ & .106 & .132 & 1.112 & $.191^{* *}$ & .057 & 1.211 \\
\hline Years of Experience & $.153^{* * *}$ & .046 & 1.166 & $.098^{* * *}$ & .016 & 1.103 \\
\hline \multicolumn{7}{|l|}{ Class rank ${ }^{\mathrm{b}}$} \\
\hline $10^{\text {th }}$ percentile & .036 & .203 & 1.037 & $.515^{* * *}$ & .073 & 1.674 \\
\hline $25^{\text {th }}$ percentile & .208 & .152 & 1.231 & $.312^{* * *}$ & .064 & 1.366 \\
\hline $75^{\text {th }}$ percentile & .002 & .190 & 1.002 & -.134 & .063 & .847 \\
\hline Income (logged) & .200 & .097 & 1.221 & $.368^{* * *}$ & .038 & 1.445 \\
\hline Metropolitan Area $^{c}$ & -.147 & .155 & .863 & $-.165^{*}$ & .070 & .848 \\
\hline Debt remaining & $-.195^{* * *}$ & .043 & .823 & -.155 & .018 & .857 \\
\hline \multicolumn{7}{|l|}{ Occupation ${ }^{\mathrm{d}}$} \\
\hline In-house counsel & -.367 & .214 & .693 & -.156 & .083 & .855 \\
\hline Non-profit/public interest & -.212 & .281 & .809 & .217 & .159 & 1.242 \\
\hline Government & -.214 & .159 & .807 & -.045 & .077 & .956 \\
\hline Non-law & $-1.027^{* *}$ & .337 & .358 & -.594 & .155 & .552 \\
\hline Intercept 5 & -2.211 & 1.158 & & -4.728 & .447 & \\
\hline Intercept 4 & -.906 & 1.156 & & -2.218 & .445 & \\
\hline Intercept 3 & .309 & 1.157 & & -2.095 & .444 & \\
\hline Intercept 2 & 1.484 & 1.163 & & -.963 & .446 & \\
\hline $\operatorname{LR} \chi^{2}$ & 138.210 & & & 691.003 & & \\
\hline Prob $>\chi^{2}$ & .000 & & & .000 & & \\
\hline Pseudo R-Square & .157 & & & .151 & & \\
\hline $\mathrm{N}$ & 1449 & & & 7279 & & \\
\hline
\end{tabular}

Note: ${ }^{* *} p<.01 ;{ }^{* * *} p<.001$ (two-tailed test).

Includes information of the study sample of all full-time working attorneys.

a Reference is male.

b Class rank, reference is $50^{\text {th }}$ percentile class rank.

c Metropolitan Area $=1$ and non-metropolitan $=0$.

d Occupation, reference group is private practice.

Table 5

White and Minority Private Practitioners' Satisfaction by Role (ordered logit).

\begin{tabular}{|c|c|c|c|c|c|c|}
\hline & \multicolumn{3}{|l|}{ Minorities } & \multicolumn{3}{|l|}{ White } \\
\hline & Estimate & Std. Err & Odds & Estimate & Std. Err & Odds \\
\hline Female $^{a}$ & -.106 & .174 & .899 & $.312^{* * *}$ & .073 & 1.336 \\
\hline Years of Experience & $.134^{*}$ & .067 & 1.143 & $.112^{* * *}$ & .023 & 1.118 \\
\hline \multicolumn{7}{|l|}{ Class rank $\mathrm{b}^{\mathrm{b}}$} \\
\hline $10^{\text {th }}$ percentile & -.034 & .261 & .966 & $.454^{* * *}$ & .091 & 1.575 \\
\hline $25^{\text {th }}$ percentile & .120 & .198 & 1.275 & $.184^{*}$ & .079 & 1.202 \\
\hline $75^{\text {th }}$ percentile & .229 & .283 & 1.257 & -.133 & .125 & .875 \\
\hline Income (logged) & .158 & .125 & 1.171 & $.416^{* * *}$ & .048 & 1.516 \\
\hline Metropolitan Area ${ }^{c}$ & -.118 & .205 & .888 & -.158 & .086 & .854 \\
\hline Debt remaining & $-.190^{* * *}$ & .058 & .827 & $-.132 * * *$ & .022 & .876 \\
\hline \multicolumn{7}{|c|}{ Private Practice Characteristics } \\
\hline Firm Size & .005 & .003 & 1.005 & .001 & .001 & 1.001 \\
\hline \multicolumn{7}{|l|}{ Role $^{\mathrm{d}}$} \\
\hline Solo & $.467^{*}$ & .224 & 1.595 & $.273^{* *}$ & .094 & 1.314 \\
\hline Equity Partner & .091 & .386 & 1.095 & .087 & .113 & 1.091 \\
\hline Nonequity & .549 & .469 & 1.731 & -.102 & .142 & .903 \\
\hline Other & -.223 & .365 & .800 & -.239 & .142 & .787 \\
\hline Intercept 5 & -1.789 & 1.377 & & -5.485 & .556 & \\
\hline Intercept 4 & -.454 & 1.375 & & -4.116 & .552 & \\
\hline Intercept 3 & .854 & 1.376 & & -2.844 & .551 & \\
\hline Intercept 2 & 1.875 & 1.386 & & -1.762 & .553 & \\
\hline $\mathrm{LR} \chi^{2}$ & & 84.310 & & & 473.590 & \\
\hline Prob $>\chi^{2}$ & .000 & & & .000 & & \\
\hline Pseudo R-Square & .163 & & & .154 & & \\
\hline $\mathrm{N}$ & 1225 & & & 4827 & & \\
\hline
\end{tabular}

Note: ${ }^{*} p<.05 ;{ }^{* *} p<.01 ;{ }^{* * *} p<.001$ (two-tailed test).

Includes information of the study sample of all full-time working attorneys.

a Reference is male.

b Class rank, reference is $50^{\text {th }}$ percentile class rank.

c Metropolitan $=1$ and non-metropolitan $=0$.

d Role $=$ reference group is associate attorney.

yearly income for white private practitioners is $\$ 130,000$ compared to $\$ 100,000$ for minority private practitioners.

Although the sources of these racial pay disparities are beyond the purview of this article, possible causes include practice experience, gender, and large firm employment (see also Dinovitzer et al., 2009a,b: 834-35; Kay and Hagan, 1995: 297; Monahan and Swanson, 2009: 470; Simkovic and McIntyre, 2014: 271-72). As shown in Table 1 , in comparison to white attorneys, minority attorneys have less experience and are more likely to be female and to occupy non-partnership roles. Implicit or explicit bias could also 


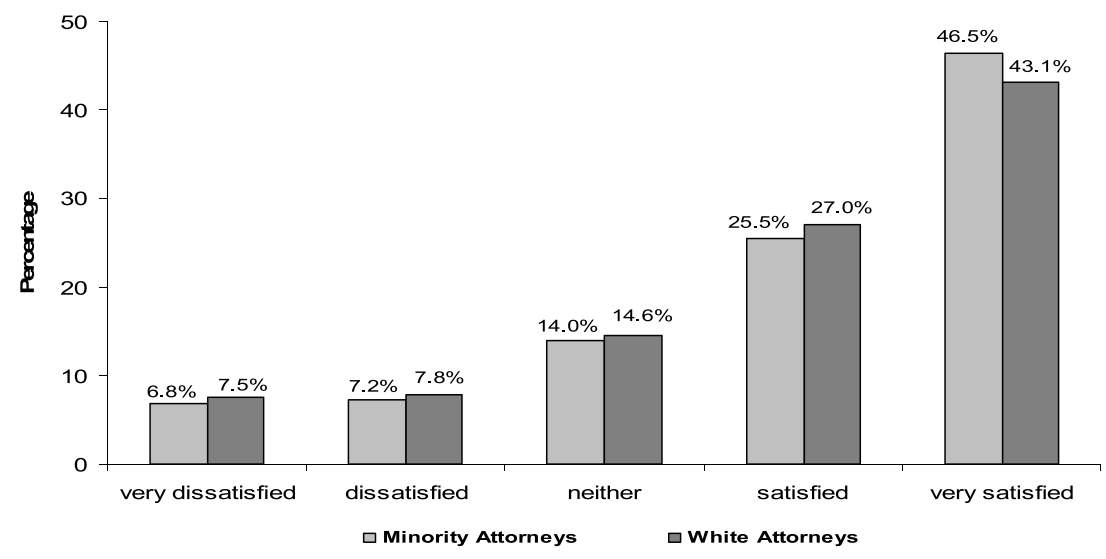

Fig. 1. Categories of Satisfaction by Race.

play a role, particularly if it deprives racial minorities of lucrative partner positions within firms (Gorman and Kay, 2010, 214; Wilkins and Mitu Gulati, 1996: 541-42).

Since the minority attorneys report substantially lower incomes than white attorneys, one would expect minority attorneys to report lower satisfaction with their decisions to attend law school. Yet, as set out in the next section, this is far from the case.

\subsection{Minority attorneys' satisfaction}

Our data suggest that most attorneys - regardless of their race - are satisfied with their decisions to attend law school. Fig. 1 diagrams the satisfaction of the white and minority attorneys in the study sample across our five-point scale. As Fig. 1 shows, $72 \%$ of minority attorneys and $70.1 \%$ of white attorneys are either very satisfied or satisfied with the decision to attend law school. The mean satisfaction of the white and non-white attorneys is also equivalent (mean of 4.2). These findings align with previous research that has found no significant differences in attorney satisfaction by race (Wilder, 2008: 44). That the minority attorneys in our study sample report the same satisfaction as white attorneys while earning less and working in nominally lower status positions illustrates the paradox of minority attorney satisfaction.

These descriptive results may in fact understate minority attorneys' satisfaction. To determine if minority status is associated with higher levels of satisfaction, in Table 2 we conduct an ordered logit regression analysis, examining differences in satisfaction among full-time attorneys by occupation. This allows us to ascertain whether race is driving minority attorneys' high satisfaction as opposed to other factors, such as minority attorneys' sorting into ostensibly more rewarding occupational settings (Dau-Schmidt and Mukhopadhaya, 1999: 362-63).

The results in Table 2 demonstrate that several factors affect attorneys' satisfaction. Employment in a non-law related field, the carrying of law school debt, and low class rank decrease the odds of satisfaction. By way of contrast, higher incomes and superior academic performance increase satisfaction. Female gender also has a small positive effect.

The most meaningful finding concerns race. After controlling for income, occupation and other factors, minority attorneys' satisfaction far outpaces that of white attorneys. Specifically, minority attorneys are almost $51 \%$ more likely to be satisfied with their decisions to attend law school than similarly situated white attorneys.

Much of the legal profession research examining racial differences in satisfaction has focused on private law firms (Payne-Pikus et al., 2010; Sander, 2006). To test whether our finding of high satisfaction among minority attorneys holds with respect to this important subgroup, we conduct an additional ordered logit regres- sion in Table 3, while adding firm size and role to the independent variables.

The results for the private practitioner sample are similar to those for the full study sample presented in Table 2. Debt and academic performance continue to be associated with lower odds of satisfaction, while higher income and class rank are associated with higher odds. In terms of the newly introduced variables in Table 3, firm size has no effect on satisfaction while private practitioners who work as solos have $34 \%$ greater odds of satisfaction than associates. Interestingly, partnership status does not affect satisfaction, suggesting that the benefits of partner positions may mostly be pecuniary. ${ }^{11}$

Table 3 also demonstrates that race has a substantial effect on private practitioners' satisfaction: minority private practitioners are nearly $58 \%$ more likely to be satisfied with their decisions to attend law school than their white counterparts.

The dominant narrative of minority attorneys struggling to make headway in the white-dominated profession is belied by minority attorneys' high satisfaction with their career choice. In the next section, we assess whether different factors may drive the satisfaction of white and non-white attorneys and thereby give rise to the paradox of minority attorney satisfaction.

\subsection{Minority attorneys' differing perspectives}

We have theorized that white and non-white attorneys assess their decisions to attend law school differently and that these differences account for the paradox of minority attorney satisfaction. To test this proposition, we ran separate ordered logit regression analyses for white and minority attorneys' satisfaction, allowing us to identify the determinants of satisfaction for each group. If our theory is supported, then prestige markers such as high incomes and employment in large law firms should not be predictive of minority attorneys' satisfaction.

Table 4 compares the predictors of satisfaction for white and minority attorneys. We diagram the significant estimated coefficients for each group in Fig. 2.

Our analyses demonstrate that debt and particularly employment in a non-law related field decrease the odds of satisfaction for both white and non-white attorneys. However, salient differences between white and non-white attorneys also emerge. Table 4 shows that, for white attorneys, every unit $(\$ 10,000)$ increase in income is associated with a $45 \%$ increase in the odds of satisfaction. Academic performance is also integral to white attorneys: grad-

\footnotetext{
11 The median equity partner in our study sample earns $\$ 240,000$ compared to
} $\$ 95,000$ for the median law firm associate. 


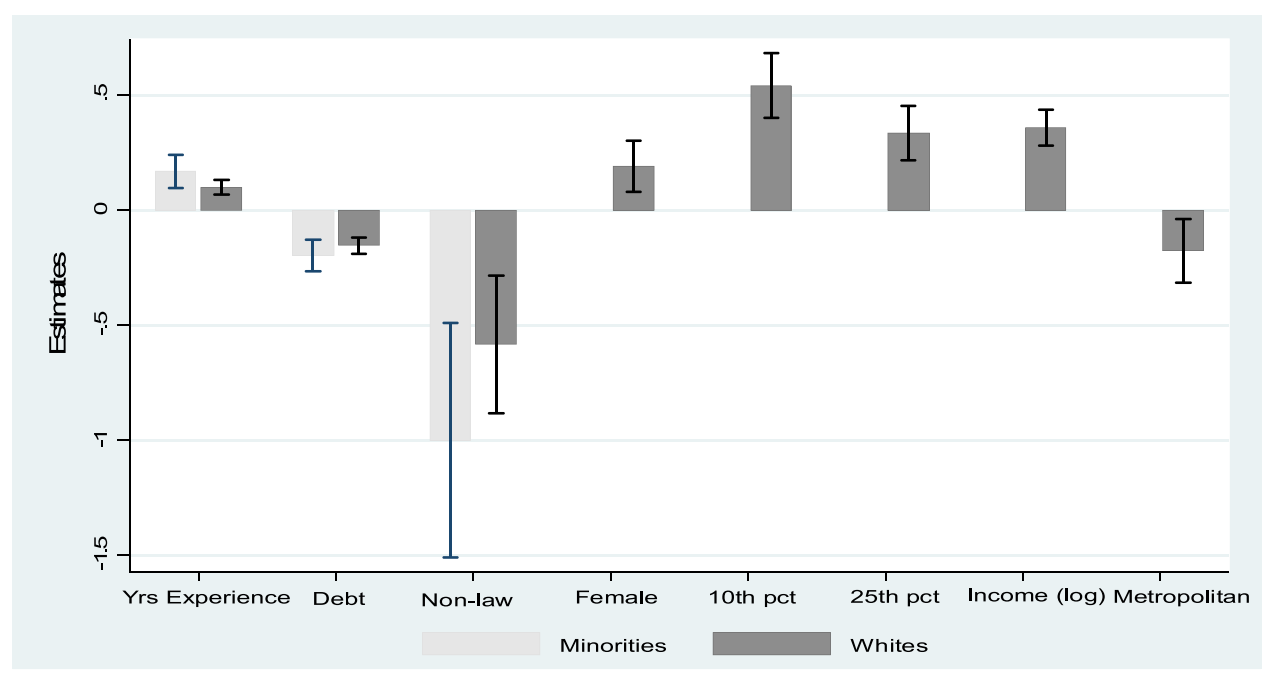

Fig. 2. Significant Estimates for White and Minority Attorneys' Satisfaction (with confidence intervals).

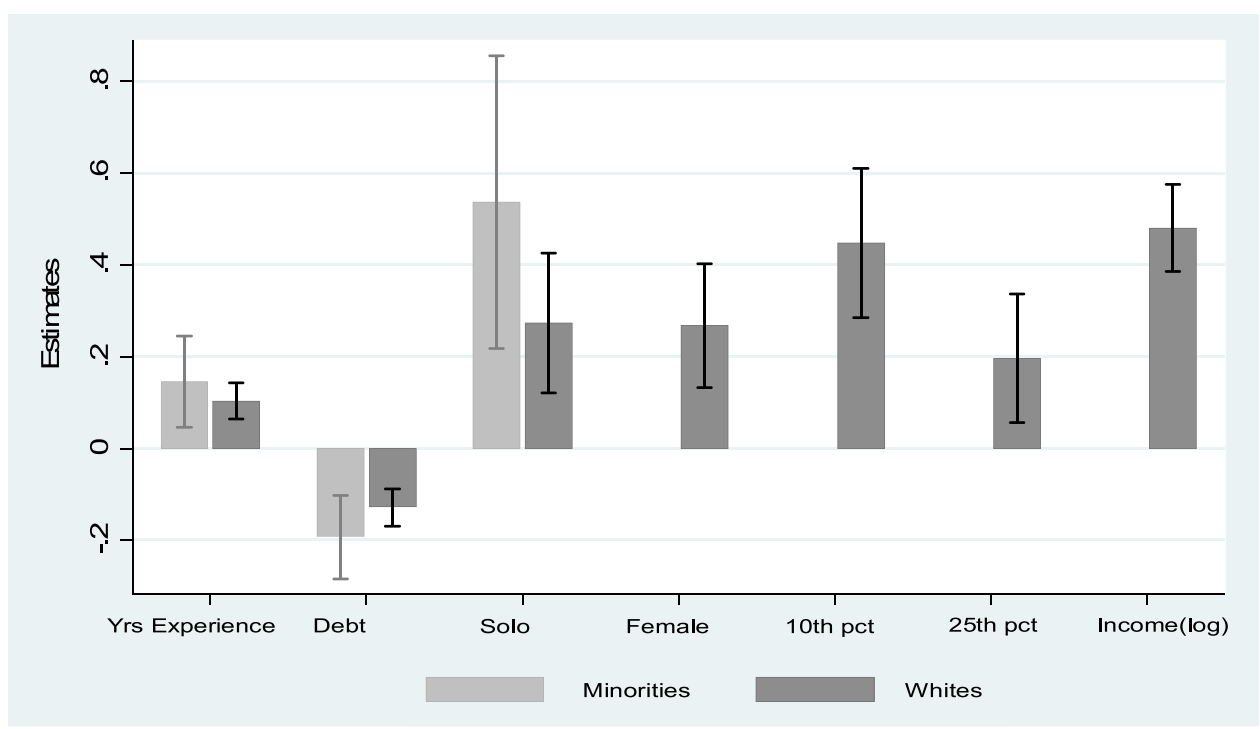

Fig. 3. Significant Estimates for White and Minority Private Practitioners' Satisfaction (with confidence intervals).

uating in either the $10^{\text {th }}$ or $25^{\text {th }}$ percentile increases the odds of satisfaction by $67 \%$ and $37 \%$ respectively. Conversely, among minority attorneys, neither income nor higher class rank has any effect. The first finding is especially notable because earlier scholarship has contended that income produces the strongest and most consistent effect on attorneys' satisfaction Heinz et al., 2005: 273). More recent large-scale research has questioned the centrality of income (Krieger and Sheldon, 2015: 623), and the received wisdom that attorneys' satisfaction depends largely on income is especially dubious with respect to minority attorneys.

In Table 5, we repeat our regression analyses on the satisfaction of the subsample of white and minority private practitioners while including firm size and role among the observed variables. Fig. 3 illustrates the significant coefficient estimates for each group.

When considering only the satisfaction of private practitioners in the study sample, income and academic performance continue to affect the satisfaction of white attorneys but not that of minority attorneys. Among white private practitioners, every unit increase in income leads to $52 \%$ higher odds of satisfaction; graduating in the $10^{\text {th }}$ and $25^{\text {th }}$ percentile of their law school classes also increases the odds of satisfaction (by $58 \%$ and $20 \%$ respectively). Employment as a solo practitioner is also associated with higher odds of satisfac- tion for both groups although the effect is larger among minority attorneys (60\% versus $31 \%$ among white attorneys). Neither class rank nor income has a significant effect on minority private practitioners' satisfaction.

In sum, we find that white and minority attorneys differ somewhat with respect to the factors that affect their satisfaction with the decision to attend law school. For both groups, satisfaction is impacted by debt and working in non-law related roles. However, as hypothesized, minority attorneys' satisfaction is not predicated on prestige markers such as high incomes and class rank.

\section{Discussion}

\subsection{Understanding the professional satisfaction of minority attorneys}

Critical race theory has long emphasized the centrality of the lived experiences of marginalized groups (Mutua, 2006a,b: 355). However, scholars have largely presupposed that minority attorneys assess their careers using the same criteria that white attorneys do while highlighting ways in which minority attorneys' careers purportedly fall short (Johnson, 1999: 1014-20; Payne- 
Pikus et al., 2010: 559-60). Our findings provide evidence that white lawyers' careers should not necessarily serve as benchmarks.

Certain extrinsic markers of success are integral to white attorneys. Class rank and higher incomes are strongly associated with white attorneys' satisfaction although partnership status is not. With respect to minority attorneys, the paradigm for satisfaction is more elusive. Minority attorneys' satisfaction is unaffected by their academic performance and income, as well as partnership status. In law, unlike most other fields, non-white workers appear to be less concerned with income and other extrinsic awards than white workers (see also Kashefi, 2011: 658).

Of course, our findings do not signify that academic achievement and financial security are unimportant to minority attorneys. Graduation from law school and bar exam passage depend on academic performance, and minority attorneys may be attracted to the legal profession initially because of the financial rewards. However, once they gain access to the profession and secure a relatively comfortable "bourgeois" existence (Dinovitzer and Garth, 2007:3), other concerns predominate. ${ }^{12}$

The low rate of partnership among minority attorneys has understandably concerned scholars (Payne-Pikus et al., 2010; Woodson, 2016), but we find that winning the "promotion to partner tournament" does not affect the satisfaction of either white or non-white attorneys (Galanter and Palay, 1994). Although American lawyers have viewed partner positions, particularly in corporate law firms, as the epitome of success and prestige in the legal profession since the early part of the twentieth century (Abel, 1989: 178-82; Garth and Sterling, 2017: 133-34) ascending to these positions does not increase satisfaction with career path choice.

Our finding that partnership status does not affect minority attorneys' satisfaction may signify a general devaluation of these positions (see Galanter and Henderson, 2007: 1879-80) but could also connote that minority attorneys were never particularly invested in professional hierarchies that crystallized when they were excluded from the profession (Smigel, 1969:45) and valorize service to corporate clients while expecting "bleached out professionalism" of lawyers (Wilkins, 1998: 153).

In the present day, the splintering of the legal profession's homogeneity also affords opportunities outside of historically white-dominated corporate law firms (Sommerlad, 2007: 2016). For some minority attorneys, law firms may serve as mere stopping off points, allowing them to acquire sufficient social capital to be able to pursue other desirable opportunities. One common career strategy is to parlay law firm positions into corporate in-house positions, which generally afford high pay with more flexibility in schedule (Garth and Sterling, 2017:59-60). Another is to transition to smaller, boutique practices that primarily service minority clientele (ibid: 77-78). AJD's third wave also reports a significant influx of minorities from private practice into the government (Dinovitzer et al., 2014a,b: 72-73). The high attrition rates of minorities from corporate law firms merit scrutiny; however, many minority attorneys who leave these firms find themselves practicing in roles that may be more consistent with their long-term values and interests (Pratt, 2012: 1992-93).

Empirical research demonstrates that racial minorities are more likely than other groups to join the legal profession to help others and to empower their communities (Cruz and Molina, 2009:100607; Sommerlad, 2007: 2004; Wilder, 2008: 51). Once in practice, they tend to be more interested in public service (Lempert et al., 2000: 401; Root, 2014: 594-95). These values are not necessarily compatible with life-long careers in corporate law firms, which

\footnotetext{
12 Scholars have claimed that extrinsic awards are "taken for granted" among highly educated groups (see, e.g., Kashefi, 2011, 654; Wilson, 2010: 9).
}

can require minorities to reinforce racial inequalities directly or indirectly (Wilkins, 1993: 1983-84).

Minority attorneys who are successful in attaining partner positions in law firms may also find that their elevated status fails to protect them from institutional discrimination and bias (Collins et al., 2017: 1642; Cruz and Molina, 2009: 1014-1018). This bias can manifest itself in a variety of ways, from exclusionary practices to racialized jokes and stereotyping (Pratt, 2012: 1785; Sommerlad, 2007: 208). To traverse firm environments successfully, minority attorneys must often compromise with the dominant white culture or assimilate entirely (Tomlinson et al., 2013: 257-59).

The substantial focus on the plight of minorities in large corporate law firms also elides that the vast majority of attorneys, white and non-white, work in small firms (see Table 1). According to our analyses, larger firm size has no bearing on attorney satisfaction. ${ }^{13}$ Conversely practicing as a solo practitioner is among the strongest predictors of satisfaction for both white and non-white attorneys.

The satisfaction of solo practitioners is difficult to reconcile with descriptions of solo practice as lacking in prestige and its practitioners bereft of social capital (Dinovitzer, 2006: 464-65; Heinz et al. 95-96). The dominant narrative has been very much one of decline. Nearly thirty years ago Abel warned that:

Solo practice. . . will continue to contract in response to the growing complexity of the law and the need to specialize. . . [T] he professional ideal no longer is the "autonomy" of being one's own boss but the material security afforded by the large enterprise (1989: 233).

Recent accounts have echoed this assessment while emphasizing increased competition from non-lawyer providers of legal services, including internet providers (Barton, 2014: 31-32).

Solo practitioners may face substantial challenges, but these challenges have not affected their satisfaction. ${ }^{14}$ After controlling for income and other factors, solos are far more satisfied than other private practitioners, including equity partners. The 2008 economic recession also took a significant toll on law firms and may have increased the appeal of "being one's own boss" (Burk, 2014: 53; Markovic and Plickert, 2018: 162).

Minority attorneys are especially satisfied in solo practice. Our ordered logit regression analysis indicates that minority solos have $60 \%$ higher odds of satisfaction than minority associates. They are also more satisfied than white solos. ${ }^{15}$

A number of factors probably contribute to minority solos practitioners' high satisfaction. Most obvious is that minority solos work for themselves and are less likely to face discrimination in their workplaces. They do not have to concern themselves with fitting into the prevailing firm culture or locating just the right firm "silo" (Garth and Sterling, 2017: 156). These attorneys also have more autonomy in terms of which matters to take, their hours, and how to complete their work (Kay, 1997:324-25; Seron, 1996:12). Minority attorneys in larger firms often lack this autonomy because of superiors' tendency to implicitly or explicitly view them as less competent than their white peers (Woodson, 2015: 559). In con-

\footnotetext{
13 However, firm size may affect satisfaction through its interaction with income. Income tends to rise with firm size (Kay and Hagan, 1995: 297; Monahan and Swanson, 2009: 470). The median attorney in our study sample who works for a firm with over 400 lawyers earned \$210,000 in 2015.

14 It is possible, as Garth and Dinovitzer have suggested, that solo practitioners are satisfied with their practice settings and social opportunities but lag other attorneys in satisfaction with income and advancement (2007:20).

15 The mean satisfaction of minority solos in the study sample is 4.6 out of 5 whereas the mean satisfaction of white solos is 4.2 . This difference is significant $(\mathrm{p}<.05)$.
} 
temporary legal practice, even minority equity partners will find themselves answerable to, and at the mercy of, other partners. ${ }^{16}$

In addition, solo practitioners generally represent individuals as opposed to corporations (Levin, 2004: 320; Heinz and Laumann, 1982: 11). For minority solos, their clients will generally be members of their own racial communities and service to these communities can be a source of meaning and pride (Cruz and Molina, 2009: 1018; Ryff et al., 2003: 288). They "give back" to their communities by providing needed legal services to community members but also by assuming leadership roles (Lempert et al., 2000: 449; Pan, 2017: 142). Thus minority solo practitioners are able to blend legal practice and community service in a way that most other private practitioners cannot (Garth, 2004: 108). The experience of one Mexican-American AJD participant, who transitioned from a larger firm to solo practice, is instructive:

One of the things that I've done is since I left [the larger firm], a couple weeks after I left, I was appointed to the school board for ... here in the city... And since then, I've been elected into office. So, for the last two years, I've been the president of the school board .... I also sit on a couple of different boards. I sit on the board for the YMCA here .... And I sit on the board for the Hispanic Bar Association for the first three and a halfyears, four years now (Garth and Sterling, 2017: 74).

Minority attorneys in other settings also receive service opportunities but may not have the latitude to take advantage of them. ${ }^{17}$

Legal careers often require tradeoffs between, inter alia, higher incomes and more satisfying workplace settings (Markovic and Plickert, 2018:159). Minority solo practitioners make prudent trade-offs because any sacrifices that they make in terms of income or prestige to work for themselves do not detract from their satisfaction.

\subsection{Sources of satisfaction differences}

The foregoing discussion raises the question of why the drivers of white and minority attorneys' satisfaction should differ. As this study is not longitudinal, we cannot determine definitively whether the minority attorneys in our study sample have unique values that pre-date their entry into the legal profession or whether they are socialized differently qua members of the profession. Nevertheless, both mechanisms likely help to explain the observed differences in white and non-white attorneys' satisfaction.

As noted in the previous section, aspiring minority attorneys appear to enter the legal profession for different reasons than their white counterparts. For example, minority students are more likely than white students to identify service to their communities as a motivation for attending law school (Sommerlad, 2007: 203-04). Other research evinces racial minorities' consciousness of "righting wrongs" and advancing equality for racial communities (Pan, 2017: 38). It stands to reason that attorneys committed to social justice and aiding their communities would be less likely to assess their careers with reference to their grades or incomes (Pratt, 2012: 1793).

Research also indicates that minority attorneys potentially undergo different professional socialization processes (Cruz and Molina, 2009; Holmquist et al., 2014). The paucity of racial minori-

\footnotetext{
16 Most firms rely on "rainmaker" partners to originate business that is handled on a day-to-day basis by so-called "service partners." The former types of partners have far more power and bargaining leverage within their firms (Regan and Rohrer, 2012: 97-101).

17 In addition to time and schedule pressures, attorneys in larger firms may be wary to engage in activities that could give rise to conflicts of interest, which, under prevailing rules of legal ethics, are imputed firm-wide and may force their firms to decline business (see Model Rules of Professional Conduct R. 1.10 (2017)).
}

ties in legal practice means that aspiring minority attorneys have had less access to mentors who are able to instruct them on the legal profession and its hierarchies (Holmquist et al., 2014: 569). In a 2011 empirical study of Hispanic female attorneys, a striking $78 \%$ stated that they did not have exposure to attorney role models prior to joining the profession; for the attorneys who did have role models, they were usually small firm practitioners in their communities (Cruz and Molina, 2009: 1004). Without this exposure to the profession and particularly its more "elite" echelons, minority attorneys are apt to emulate the careers of the attorneys already embedded in their communities (Sommerlad, 2007:204).

Other socialization forces are undoubtedly relevant as well. White students and lawyers often feel family and community pressure to excel academically and to earn substantial incomes. According to Wilkins, the pressure on minority law students and lawyers is to "represent their people" (Wilkins 2010-2011:993). If this description is accurate, then it is natural that minority attorneys would place less emphasis on class rank or income and that they would derive satisfaction in nominally low status solo practitioner roles.

Lastly, the role of law school socialization also merits some consideration. A number of studies show that law schools precipitate a change in entering students' values and beliefs such that they experience "public interest drift" (Bliss, 2018: 1975). Erlanger and Klegon provide some support for this theory by showing that law students come to associate corporate transactional work with substantially greater prestige than they did at the beginning of law school (Erlanger Howard and Klegon, 1978: 25). More recently, Krieger and Sheldon have documented that law students become more concerned with grades and other appearance values and less concerned with service to their communities (Krieger and Sheldon, 2004: 280-81). Scholarship continues to explore whether these changes are a function of students' relatively weak pre-law school commitments or law schools' ostensibly corporatist orientations (Bliss, 2018: 2000-2002).

A key limitation of this literature is that it concentrates predominately on white law students. Minority students may have stronger pre-law school commitments than their white peers or could be less susceptible to any alleged corporatist indoctrination. The dearth of minority role models on law school faculties (Carson, 2013: 8-10; Pan, 2017: 66-67) may render law school socialization largely ineffectual with respect to minority students such that they will not forego their pre-law school commitments to strive for lucrative associate positions. ${ }^{18}$ All of these possibilities furnish fertile opportunities for future research.

\section{Limitations}

This study has made advances in explaining the paradox of minority attorney satisfaction by highlighting the factors that affect the satisfaction of white and non-white attorneys. However, the present study is limited in certain respects.

First, this research has relied on data from a large cross-section of Texas lawyers. According to the 2016 Census, Texas's population is $43 \%$ white, $39 \%$ Hispanic, and $13 \%$ Black. The presence of sizeable minority communities in Texas may yield advantages for Hispanic and Black attorneys, from potential business development opportunities to supportive professional and personal networks. ${ }^{19}$ Minority attorneys in more racially homogenous states may have less support, as well as fewer professional pathways out-

\footnotetext{
18 Associate positions in corporate law firms are especially valued by law schools (Erlander and Klegon, 1978: 14; Nader, 1970: 493).

19 There is some evidence that Hispanic individuals are particularly reliant on their community networks for job-seeking (Wei-Cheng and Kopischke, 2001).
} 
side of white-dominated law firms, possibly undermining their satisfaction. ${ }^{20}$ Moreover, there are likely important differences between groups of minority attorneys that fall outside of this study's purview.

Second, our data do not include State Bar members' socioeconomic backgrounds, including the law schools that they attended. The inclusion of these attributes could affect the analysis because lawyers from more elite backgrounds tend to have higher career expectations (Dinovitzer and Garth, 2007: 21-23). If the minority attorneys in our study sample are of lower socioeconomic status than their white colleagues, their higher satisfaction may be a consequence of socioeconomic status and not race.

We are skeptical that differences in socioeconomic status account for the differences in our satisfaction results. As Sander's appraisal of $A J D$ data suggests, law students, including minority law students, are generally of high socioeconomic status (Sander, 2011:647-48). They also by and large enter law school with modest expectations for their careers, which tend to become even more pronounced as they are socialized into the profession (Erlanger et al., 1996:854; Erlanger Howard and Klegon, 1978:29; Heinz et al., 2005, 1998). Differences between white and non-white attorneys based on socioeconomic status are also diminishing (Heinz et al., 2005: 65).

That the high satisfaction of minority attorneys is attributable to their allegedly lower socioeconomic status is also difficult to reconcile with this study's central finding that different factors drive the satisfaction of white and non-white attorneys. Individuals with lower economic status should be more concerned with income and other extrinsic rewards, not less (Kashefi, 2011: 651; Shapiro, 1977: 27). Indeed, one would expect purportedly socioeconomically disadvantaged minority attorneys to be very satisfied when they secure the most lucrative private practice positions (see Dinovitzer and Garth, 2007:29-30), but these attorneys are no more satisfied than their lower-earning peers.

\section{Conclusion}

This study has contributed to the empirical literature on attorneys' professional satisfaction while analyzing racial differences in satisfaction. We have demonstrated that, notwithstanding employment in nominally lower status positions and substantially lower incomes, minority attorneys are as satisfied with their decisions to attend law school as white attorneys are. Minority race is associated with higher odds of satisfaction for attorneys generally, as well as for private practitioners.

This seeming paradox of minority attorney satisfaction stems from the fact that minority attorneys' satisfaction does not depend on the attainment of prestige markers such as graduation at the top of one's law school class, high incomes, or promotion to equity partner positions. Discrimination undoubtedly plays a role in minority attorneys' career choices, but their high satisfaction in the legal profession, and particularly in practice settings such as solo practice, indicates that their satisfaction is not wedded to prevailing hierarchies and markers of success. Future research should examine if this is a function of minority attorneys' adaption to the discrimination that they face or that they are finding career pathways that allow them to fulfill important goals such as the advancement of their communities' interests.

Racial minorities' challenges in the legal profession have not detracted from their satisfaction. The secret to their success appears

\footnotetext{
20 But see Koh et al., 2016:138 (finding that location within the United States does not affect the satisfaction of Black workers); Heinz et al., 2005272 (finding that Black attorneys are less satisfied in the racially diverse, but highly segregated, city of Chicago).
}

to be that they have not fully internalized the dominant values of a profession that long excluded them.

\section{Acknowledgement}

This research was supported by the AccessLex Institute, United States of America, Grant \# FY15DG0003.

\section{References}

Abel, Richard L., 1989. American Lawyers. Oxford University Press, Oxford.

Allison, Paul, 2012. Logistic Regression Using SAS: Theory and Application, second edition. SAS Institute Inc., Cary NC.

Auerbach, Jerold, 1976. Unequal Justice: Lawyers and Social Change in Modern America. Oxford University Press, Oxford.

Bartel, Ann P., 1981. Race differences in job satisfaction: a reappraisal. J. Hum. Resour. 16, 294-303.

Barton, Benjamin H., 2014. A glass half full look at the changes in the American legal market. Int. Rev. Law Econ. 38, 29-42.

Bell, Joyce M., Hartmann, Douglas, 2007. Diversity in everyday discourse: the cultural ambiguities and consequences of Ḧappy Talk: Am. Sociol. Rev. 72, 895-914.

Bliss, John, 2018. From idealists to hired guns? An empirical analysis of "Public Interest Drift" in law school. U.C. Davis L. Rev. 51, 1973-2032.

Burk, Bernard A., 2014. What's new about the new normal: the evolving market for new lawyers in the 21st century. Fla. St. L. Rev. 41, 541-608.

Carbado, Devin W., 2011. Critical What? Conn. L. Rev. 43, 1593-1643.

Carle, Susan D., 2001. Re-valuing lawyering for middle-income clients. Fordham L. Rev. 70, 719-746.

Carson, Loftus C., 2013. Employment opportunities and conditions for the African-American legal professoriate: perspectives from the inside. Tex. J. CL CR 19, 1-108.

Clark, Andrew E., 1997. Job satisfaction and gender: why are women so happy at work? Labour Econ. 8, 341-372.

Clydesdale, Timothy T., 2014. A forked river runs through law school: toward understanding race, gender, age, and related gaps in law school performance and bar passage. Law Social Inquiry 29, 711-769.

Collins, Todd A., Dumas, Tao L., Moyer, Laura P., 2017. Intersecting disadvantages: race, gender, and age discrimination among attorneys. Soc. Sci. Q. 98, $1642-1658$

Cruz, Jill L., Molina, Melinda S., 2009. Hispanic National Bar Association National Study on the status of Latinas in the legal profession-few and far between: the reality of Latina lawyers. Pepp. L. Rev. 37, 971-1038.

Dau-Schmidt, Kenneth G., Mukhopadhaya, Kaushik, 1999. The fruits of our labor: an empirical study of the distribution of income and job satisfaction across the legal profession. J. Legal Educ. 49, 342-346.

Dau-Schmidt, Kenneth G., Stake, Jeffrey E., Mukhopadhaya, Kaushik, Haley, Timothy A., 2006. The pride of Indiana: an empirical study of the law school experience and careers of Indiana University School of Law-Bloomington Alumni. Ind. LJ 1427, 478.

Dinovitzer, Ronit, 2006. Social capital and constraints on legal careers. 40 Law Soc. Rev. 81, 445-480.

Dinovitzer, Ronit, Garth, Bryant G., 2007. Lawyer satisfaction in the process of structuring legal careers. Law Soc. Rev. 41, 1-50.

Dinovitzer, Ronit, Reichman, Nancy, Sterling, Joyce, 2009a. The differential valuation of women's work: a new look at the gender gap in lawyers' incomes. 88 Social Forces 63, 819-864.

Dinovitzer, Ronit, Nelson, Robert, Plickert, Gabriele, Sandefur, Rebecca, Sterling, Joyce, Adams, Terry, Garth, Bryant, Hagan, John, Wilder, Gita, Wilkins, David, 2009b. After the JD II: Second Results From a National Study of Legal Careers. American Bar Foundation, Dallas: NALP Foundation for Law Career Research and Education, Chicago.

Dinovitzer, Ronit, Garth, Bryant G., Sterling, Joyce S., 2014a. Buyers' remorse: an empirical assessment of the desirability of a legal career. J. Legal. Educ. 211-234.

Dinovitzer, Ronit, Garth, Bryant G., Nelson, Robert, Plickert, Gabriele, Sanderfur, Rebecca, Sterling, Joyce, Wilkins, David, 2014b. After the JD III: Third Results From a National Study of Legal Careers. American Bar Foundation, Dallas: NALP Foundation for Law Career Research and Education, Chicago.

Erlanger, Howard S., Cahill, Mia, Epp, Charles R., Haines, Kathleen M., 1996. Law student idealism and job choice: some new data on an old question. $30 \mathrm{Law}$ Society Rev., 851-864.

Erlanger Howard, S., Klegon, Douglas A., 1978. Socialization effects of professional school: the law school experience and student orientations to public interest concerns. Law Soc. Rev. 13, 11-35

Foley, Sharon, Kidder, Deborah L., Powell, Gary N., 2002. The perceived glass ceiling and justice perceptions: an investigation of hispanic law associates. J. Mgmt. 28, 471-496.

Fortney, Susan Saab, 1994. Am I my partner's keeper-peer review in law firms. U. Colo. L. Rev. 66, 329-373.

Fullerton, Andrew S., 2009. A conceptual framework for ordered logistic regression models. Sociol. Methods Res. 38 (2), 306-347.

Galanter, Marc, Henderson, William, 2007. The elastic tournament: a second transformation of the big law firm. Stan. L. Rev. 60, 1867-1930. 
Galanter, Marc, Palay, Thomas, 1994. Tournament of lawyers: The Transformation of the Big Law Firm. University of Chicago Press, Chicago.

Garth, Bryant G., 2004. Noblesse oblige as an alternative career strategy. Hous. L. Rev, 41, 93-111.

Garth, Bryant G., Sterling, Joyce, 2017. Diversity, hierarchy, and fit in legal careers: insight from fifteen years of qualitative interviews. Geo. J. Legal Ethics 31 123-171.

Gorman, Elizabeth H., Kay, Fiona M., 2010. Racial and ethnic minority representation in large U.S. law firms. In: Special Issue Law Firms, Legal Culture, and Legal Practice 211-238. Emerald Group Publishing Limited.

Heinz, John P., Laumann, Edward O., 1982. Chicago Lawyers: The Social Structure of the Bar. Russell Sage Foundation, and Chicago: American Bar Foundation, New York.

Heinz, John P., Hull, Kathleen E., Harter, Ava A., 1998. Lawyers and their discontents: findings from a survey of the Chicago bar. Ind. LJ 74, 735-758.

Heinz, John P., et al., 2005. Urban Lawyers: The New Social Structure of the Bar. Univ. of Chicago Press, Chicago.

Hodson, Randy., 1989. Gender differences in job satisfaction: why aren't women more dissatisfied? Sociol. Q. 30, 385-399.

Holmquist, Kristen, Shultz, Marjorie, Zedeck, Sheldon, Oppenheimer, David, 2014 Measuring merit: the Schultz-Zedeck research on law school admissions. J. Legal Educ. 63, 565-584.

Hull, Kathleen E., 1999. The paradox of the contented female lawyer. Law Soc. Rev. 33, 687-702

Hylton, Kevin, 2012. Talk the talk, walk the walk: defining critical race theory in research. Race Ethnicity Educ. 15, 23-41.

Johnson Jr, Alex M., 1997. The underrepresentation of minorities in the legal profession: a critical race theorist's perspective. Michigan Law Rev., 1005-1062.

Kay, Fiona M., 1997. Flight from law: a competing risks model of departures from law firms. Law Soc. Rev. 31, 301-335.

Kay, Fiona M., Gorman, Elizabeth, 2008. Women in the legal profession. Annu. Rev. Law Social Sci. 4, 299-332.

Kay, Fiona M., Hagan, John, 1995. The persistent glass ceiling: gendered inequalities in the earnings of lawyers. Br. J. Sociol. 46, 279-310.

Koh, Chee Weh, Shen, Winny, Lee, Tiffany, 2016. Black-white mean differences in job satisfaction: a meta-analysis. J. Vocation Behav. 9, 131-143.

Kricheli-Katz, Issi Rosen-Zvi, Ziv, Neta, 2018. Hierarchy and stratification in the Israeli legal profession. Law Soc. 52, 436-470.

Krieger, Lawrence S., Sheldon, Kennon M., 2015. What makes lawyers happy: a data-driven prescription to redefine professional success. Geo. Wash. L. Rev 83, 554-627.

Ladson-Billings, Gloria, 2010. Just what is critical race theory and what's it doing in a nice field like education? Int. J. Qual. Stud. Educ. 11, 7-24.

Lempert, Richard O., Chambers, David L., Adams, Terry K., 2000. Michigan's minority graduates in practice: the river runs through law school. Law Social Inquiry 25, 395-505.

Levin, Leslie, 2004. The ethical world of solo and small firm practitioners. Houston L. Rev. 41, 309-392.

Levinson, Sanford, 1993. Identifying the Jewish lawyer: reflection on the construction of professional identity. Cardozo L. Rev. 14, 1577-1612.

Markovic, Milan, Plickert, Gabriele, 2018. Attorneys' career dissatisfaction in the new normal. Int. J. Legal Prof. 25, 147-173.

Matsuda, Mari J., 1987. Looking to the bottom: critical legal studies and reparations. Harvard Civ. Rights-Civ. Lib. Law Rev. 22, 323-400.

McCullagh, Peter, 1980. Regression models for ordinal data. J. R. Stat. Soc. Seried B45, 109-142.

McIntyre, Frank, Simkovic, Michael, 2017. Are law degrees as valuable to minorities? Int. Rev. Law Econ. 53, 23-37.

Monahan, John, Swanson, Jeffrey, 2009. Lawyers at mid-career: a 20-year longitudinal study of job and life satisfaction. J. Empirical Legal Stud. 6, 451-483.

Mueller, Charles, Wallace, Jean, 1996. Justice and the paradox of the contented female worker. Social Psychol. Q. 59, 338-349.

Mutua, Athena D., 2006a. The rise, development and future directions of critical race theory and related scholarship. Denv. U. L Rev. 84, 329.

Mutua, Athena D., 2006b. The rise, development and future directions of critical race theory and related scholarship. Denv. U. L Rev. 84, 329.
Nader, Ralph, 1970. Law schools and law firms. Minn. L. Rev. 54, 493-502.

Organ, Jerry, 2011. What do we know about the satisfaction/dissatisfaction of lawyers? A meta-analysis of research on lawyer satisfaction and well-being. St. Thomas L. Rev. 8, 225-274.

Pan, Diana Y., 2017. Incidental Racialization. Temple University Press, Philadelphia.

Payne-Pikus, Monique R., Hagan, John, Nelson, Robert L., 2010. Experiencing discrimination: race and retention in America's largest law firms. Law Soc. Rev. 44, 553-584.

Pearce, Russell G., 2001. Lawyers as America's governing class: the formation and dissolution of the original understanding of the American lawyer's role. U. Chi. L. Sch. Roundtable 8, 381-421.

Phelan, Jo., 1994. The paradox of the contented female worker: an assessment of alternative explanations. Social Psych. Q. 57, 95.

Pratt, Carla D., 2012. Sisters in law: Black women lawyers' struggle for advancement. Mich. St. L. Rev. 2012, 1777-1795.

Regan Jr, Milton C., Rohrer, Lisa H., 2012. Money and meaning: the moral economy of law firm compensation. U. St. Thomas L.J. 10, 74-151.

Rogers, Stacy J., May, Dee C., 2003. Spillover between marital quality and job satisfaction: long-term patterns and gender differences. J. Marriage Fam. 65, $482-495$.

Root, Veronica, 2014. Retaining color. 47 U. Mich. J. L. Reform, 575-643.

Roxburgh, Susan, 1999. Exploring the work and family relationship. J. Fam. Issues 20, 771-788.

Ryff, Carol D., Keyes, Corey L., Hughes, Diane L., 2003. Status inequalities, perceived discrimination, and eudaimonic well-being: do the challenges of minority life hone purposes and growth. J. Health Soc. Behav. 44, 275-291.

Sander, Richard H., 2006. The racial paradox of the corporate law firm. North Carolina Law Rev. 54, 1755-1822.

Sander, Richard H., 2011. Class in American legal education. Denv. UL Rev. 88, 631-682.

Seron, Carroll, 1996. The Business of Practicing Law: The Work Lives of Solo and Small-firm Attorneys. Temple University Press, Philadelphia.

Simkovic, Michael, McIntyre, Frank, 2014. The economic value of a law degree. J. Legal Stud. 43, 249-289.

Smigel, Erwin Orson, 1964. The Wall Street Lawyer: Professional Organization Man?, 2nd ed. Indiana University Press, Bloomington.

Sommerlad, Hilary, 2007. Researching and theorizing the process of professional identity formation. J. Law Soc. Rev. 34, 190-217.

Sommerlad, Hilary, 2011. Minorities, merit, and misrecognition in the globalized legal profession. Fordham L. Rev. 80, 2481-2513.

Stake, Jeffrey Evans, Dau-Schmidt, Kenneth G., Mukhopadhaya, Kaushik, 2007. Income and career satisfaction in the legal profession: survey data from Indiana law school graduates. J. Empirical Legal Stud. 4, 939-981.

Tomlinson, et al., 2013. Structure, agency, and career strategies of white women and black and minority ethnic individuals in the legal profession. Hum. Relat. 66, 245-269.

Wald, Eli, 2011. A primer on diversity, discrimination, and equality in the legal profession or who is responsible for pursuing diversity and why. Geo. J. Legal Ethics 24, 1079-1142.

Weaver, Charles N., 1998. Black-white differences in job satisfaction: evidence from 21 nationwide surveys. Psychol. Rep. 83, 1083-1088.

Wei-Cheng, Mau, Kopischke, Amie, 2001. Job search methods, job search outcomes, job satisfaction of college graduates. Compar. Race Sex J. Employm. Counsel. 38, 141-149.

Wilder, Gita Z., 2008. Race and ethnicity in the legal profession: findings from the first wave of after the JD study. NALP Found. Law Career Res. Educ.

Wilkins, David B., 1993. Two paths to the mountaintop? The role of legal education in shaping the values of black corporate lawyers. Stanford L. Rev. 45, 1981-2026.

Wilkins, David B., 1998. Fragmenting professionalism: racial identity and the ideology of bleached out lawyering. Int. J. Legal Prof. 5, 141-173.

Wilkins, David B., Mitu Gulati, G., 1996. Why are there so few black lawyers in corporate law firms-an institutional analysis. Cal L. Rev. 84, 493-625.

Wilson, William J., 2010. More Than Just Race: Being Black and Poor in the Inner City. W. W. Norton \& Company, New York.

Woodson, Kevin, 2015. Race and rapport: homophily and racial disadvantage in large law firms. Fordham L. Rev. 83, 2557-2576.

Woodson, Kevin, 2016. Derivative racial discrimination. Stan. JCR CL 12, 335-387. 